\title{
Audit Firm Type and Sustainability Performance: A Study of Quoted Oil and Gas Marketing Companies in Nigeria
}

\author{
Aminu Abdullahi, Oladele Jami’u Olanrewaju, \& Moshud Nurudeen Mohammed \\ Faculty of Management Sciences, Usmanu Danfodiyo University Sokoto, Nigeria \\ aminkaura.aa@gmail.com, abdullahi.aminu@udusok.edu.ng
}

\begin{abstract}
The study specifically examines the impact of audit firm types on sustainability performance effort (health care, employment and education) of quoted oil and gas marketing company in Nigeria. The population of the study consists of all the 13 oil and gas marketing companies quoted on the Nigeria Stock Exchange as at end of the year 2020. Secondary data was sourced from the annual reports and accounts of the sampled companies for the period of 5 years (2016-2020). The dependent variables for the study were Sustainability Performance effort proxied by expenditure on education, employment and health care by the oil and gas companies, while the independent variable was audit firm type. A panel regression model was employed for the analysis as the data cuts across different firms over periods. The results revealed that there is no significant relationship between audit firm type and sustainability performance. This is evident from the p-value of 0.554 which is related to audit firm type and health care. Also, the result of the audit firm and education revealed a p-value of 0.422 and that of audit firm type and employment 0.364 . This result provided a basis for rejecting all the hypotheses. The study therefore, recommends that the oil and gas companies should continue to undertake their responsibility in the sustainability performance without any reference to whether they are being audited by any type of audit firm.
\end{abstract}

Keywords: Audit Firm Type, Sustainability, Performance, Education, Employment, Health Care.

\section{How to Cite:}

Abdullahi, A., Olanrewaju, O. J., and Mohammed, M. N. (2021). Audit firm type and sustainability performance: a study of quoted oil and gas marketing companies in Nigeria. Journal of Accounting and Taxation, 1(1). 55 - 68. DOI. https://doi.org/10.47747/jat.v1i1.477

\section{Introduction}

The current sustainability concept talks about sustainability on environmental issues, human and business practices. Sustainability can be interpreted as a development that can meet current 
needs without sacrificing future needs by considering carefully and paying attention to resource conservation (Amacha \& Dastane, 2017). Currently, the concept of sustainable development agenda has become a concern of companies in many countries. With the increasing awareness and demand for sustainability, which has become a mainstream business practice (Milne, Tregidga, \& Walton 2009). Companies that consider sustainability rationally used existing resources to achieve coefficiency and social justice (Martins, Rampasso, Anholon, Quelhas, \& Leal 2019). Companies can achieve sustainable development through business performance that considers the concept of sustainability (Escrig-Olmedo, Muñoz-Torres, FernándezIzquierdo, \& Rivera-Lirio, 2017). The economic motive of organizations is to maximize the wealth of the investors which is being achieved, in today's operations, through activities that violate or disregard environmental laws and regulations while environmentalists are concerned with how to limit or eradicate activities that impacted negatively on the environment. It is obvious from the corporate angle that attempts would continue to be made towards maximizing shareholders' wealth at the detriment of the environment because it is cheaper to do so. For instance, the emission of waste into the atmosphere is found to be harmful to the climate and invariably human existence yet many companies dispose of their industrial wastes through emission. It is high time businesses are directed in line with acceptable corporate governance codes to stem the persistent infraction against the environment.

Sustainable development transforms the role of professional accountants during the entire accounting cycle. The cycle is finished with the SR. SR requires identification of key stakeholder groups and their information needs; thorough knowledge and use of reporting standards; planning, execution and control of reporting process; management, monitoring, improvement of financial and non-financial reporting information systems; expansion of reporting indicators among environmental, social and managerial; use of new technologies, such as extensible Business Reporting Language, real-time reporting, integrated reporting (IFAC (2012).

Sustainability Reporting help companies identify economic, social, and environmental impacts and share information with stakeholders, including regulators and the wider community (Usman, 2020). Corporate governance mechanism constitutes an instrument for effectively and efficiently controlling the operations of an organization. Mechanisms such as board structure, the board size, related party transactions, and audit firm type, etc. The emphasis of this study is audit firm type because auditors are instruments or authority for ensuring compliance with regulatory frameworks or policies.

The assurance of a sustainability report (SR) serves as an independent control method in which an assurer gives an opinion in order to lend credibility to the sustainability data presented by companies. The Fédération des Experts Comptables Européens (FEE, 2006) emphasizes the significance of using a criterion to validate SRs in order to increase the level of trust among SR users. When compared to non-specialists, auditor industry specialization is seen as a kind of proficiency in delivering high-quality audits due to superior knowledge of the industry's business and client's accounting processes (Habib, 2011; DeFond \& Zhang, 2014).

Unlike financial auditing, assurance statements (ASs) for SRs are optional; as a result, managers must decide whether or not they want to inform their stakeholders about their environmental, social, and economic performance, as well as whether or not they want to 
enrich their reports by hiring an independent reviewer. Furthermore, despite the fact that assurance is supposed to test a subject against criteria (IAASB, 2010), there is no widely established standard for this assurance procedure. According to Bakker (2012) of the World Business Forum for Sustainable Development, "accountants will save the world." Accountants reduce information asymmetry and assess investment risks, establish and test standards of sustainable accounting, reporting, and auditing within the new business model, and produce integrated reporting and integrated audit. Professional accountants are reassessing their roles in light of the SDGs and corporate sustainability, with specific professional skills and involvement in governance, risk management, business analysis, decision support, due diligence, anticorruption activities, and ensuring corporate transparency.

Audit firm type is considered to be the audit firm that undertakes the audit exercise of an organization. These firms can be audited by either the Big4 Audit Firms or Non -Big 4 Audit Firms and it is expected that the quality of audit performed and institution of compliance with regulatory framework might be different. Setyahadi and Narsa (2020) and Ashok (2018), investigated corporate governance mechanism and sustainability performance using variables that include board structure, disclosure, related party transactions, shareholder rights and board procedure, firm size, etc as mechanisms for corporate governance, with no study ever conducted concerning investigating the impact of audit firm size on Sustainability performance. this study deemed it right to fill this literature gap by conducting a study on Audit Firm Size and Sustainability performance of oil and gas companies in Nigeria for a period of 5 years ranging from 2016-2020. Based on this assertion the following research objectives were formulated; to examine the effect of audit firm types on health care, to determine the effect of audit firm types on employment and to determine the effect of audit firm types on the education of quoted oil and gas marketing company in Nigeria. To achieve these objectives of the study, the following hypotheses were developed: Health Care has no significant effect on audit firm type listed oil and gas marketing companies in Nigeria, Employment has no significant effect on audit firm type listed oil and gas marketing companies in nigeria and education has no significant effect on audit firm type listed oil and gas marketing companies in Nigeria.

\section{Literature Review}

In today's business world, companies are striving more for sustainable performance by incorporating the economic, social and environmental policies in their business operations. Corporate governance plays an important role in this respect by making an effective decision about proactive sustainability practices (Arora \& Dharwadkar, 2011).

Good governance is also associated with better monitoring of social and environmental performance in a way that illegal and socially not unacceptable actions must be avoided to maintain a firm's market image. The components of corporate governance (i.e., the composition of the board, CEO duality, and board size,) could have a strong influence on sustainability performance. In a similar Vein, et al. (2014) contended that more disciplined boards (regarding board meeting attendance) and boards with a higher percentage of independent directors result in better sustainability performance. Moreover, high sustainable 
firms have more responsible boards whose incentives are closely linked to economically, environmentally and socially related activities as compared to their counterparts (Eccles et al., 2012).

According to Aras and Crowther (2008), sound governance is mostly expected to load a positive influence on sustainability performance. Also, governance and sustainability are converging through the "triple bottom line" in the firms' boardroom (Hussain et al., 2018). The governance mechanism could align the economic, social and environmental impacts and leads to sustainable value creation (Benn \& Dunphy, 2007). In particular, stakeholders' theory may explain the link between firm governance and sustainability performance in a way "the system of corporate governance shall ensure the protection of stakeholders' interest by integrating the economic, social and environmental concerns into the corporate practices and strategies (Galbreath, 2018).

\subsection{Audit Firm Type /External Assurance}

External assurance is said to enhance the credibility and reliability of sustainability reports (Braam and Peeters, 2018). The increase of the credibility of reports by third parties and by Audit firm type, in particular, is caused by more experience, better qualities and integrity (Becker, DeFond, Jiambalvo, Subramanyam, 1998). Therefore, it increases the corporate reputation as well (Simnett, Vanstraelen and Chua, 2009). Since there is increasing pressure on firms to take responsibility for their actions on sustainability issues and to provide credible reports about these issues, external assurance mostly by audit firms is a way to deal with these pressures. Another reason for issuing external assurance through audit firms is to improve stakeholder engagement because firms use their sustainability reporting process as the basis for ongoing dialogue with their stakeholders (GRI report, 2013). Braam and Peeters (2018) found that high-quality assurance reports influence decisions about sustainability issues as well. Accordingly, the high-quality external assurance further enhances the credibility and the reliability of the sustainability reports (Gürturk and Hahn, 2016). Firms that choose to issue high-quality external assurance comply with sustainability reporting guidelines, because this is what these high-quality external assurances are meant to do. Furthermore, high-quality external assurance is a very costly process and when firms are not compliant the advantages do not outweigh these costs.

\subsection{Empirical Review}

Setyahadi \& Narsa (2020) conceptually reviewed the relationship between corporate governance Mechanism and corporate sustainability performance in Indonesia. The study explores some effective corporate governance principles such as transparency, accountability, responsibility, independence, fairness, and equality to achieve business sustainability in Indonesia's setting. The results show that good corporate governance regulation in Indonesia has been improved, but the enforcement is still needed to be optimized because good corporate governance will positively impact corporate sustainability.

Maha, Rashidah \& Saeid (2020) examined the impact of ESG information disclosure on EES sustainability performance among Asian firms from 2005 to 2017. The positive ESG disclosure-EES sustainability performance relationship found in this study provides evidence that disclosing the implementation of environmental and social strategies within an effective 
system of corporate governance in the organization strengthens corporate sustainability performance. The results also show that environmental performance and social performance are significantly positively related to economic sustainable performance, indicating that the corporation's economic value and creating value for society are interdependent. In line with the stakeholder theory and the shared value theory, ESG information disclosure to all stakeholders is an important factor in creating a competitive advantage for enhancing corporate sustainability performance.

Franco \& Francesco (2020) examined the impact of Corporate Governance Mechanisms on corporate environmental performances and then tested the hypothesis against a sample of 83 Italian-listed firms, noting the characteristics of their governance and ownership structures over the five years from 2013 to 2017. We also take note of data from the firms' Sustainability Reports on emissions of greenhouse gases over the 2014-2018 five-year period. The results we obtain support the prediction, made in line with the Agency-Theory perspective, that there is a positive relationship between board independence and the adoption of environmentally responsible practices. Only partial support emerges for the hypotheses, made in line with the Resource Dependence Theory, according to which better corporate environmental performances can be obtained by increasing the resource provision of board members. In particular, we discover a positive effect of a large-size board on corporate environmental performances, but no significant effect arising from the presence of interlocked board members. Finally, our study provides support for the theoretically-based hypothesis according to which the non-economic utility (socioemotional wealth) of family ownership makes family firms likely to have better environmental performances than non-family firms.

\subsection{Theoretical Review}

This segment reviewed the related theories

\subsubsection{Agency theory}

Agency theory argues that an agent performs tasks for the principal and the agent receives decision-making authority from the principal (Jensen and Meckling, 1976). Both parties will try to maximize their utility by acting in their self-interest. Since the agent performs tasks for the principal, the principal has less inside information than the agent, meaning there is information asymmetry between both parties. The dispersion between ownership and management is the prime example of the agency problem (Jensen and Murphy, 1990). In this situation, management and shareholders have conflicting interests. Management can behave in their interest, which is to work with the least amount of effort possible, while the shareholders want a higher return on their shares. To mitigate the information asymmetry, managers decide to disclose information (Brammer and Pavelin, 2006). Managers have incentives to report to show investors that they behave optimally (Watson, Shrives and Marston, 2002). Shareholders also incur monitoring costs as a result of controlling management in the pursuit of optimal behavior and reduction of information asymmetry (Jensen and Murphy, 1990). In this process, corporate governance mechanisms play an important role. Corporate governance mechanisms have both the potential to monitor and control management and have an important role in the reporting process (Shleifer and Vishny, 1997). Sustainability reporting is still voluntary and 
managers can choose whether to fully disclose relevant and reliable information (Bebbington et al., 2014).

\subsubsection{Voluntary disclosing theories}

Two seemingly opposing theories are prominent in the literature on voluntary disclosure of sustainability information that is; the legitimacy and the signaling theory. Signaling theory suggests that firms with superior sustainability performance (sp) will disclose their performance to distinct themselves from firms with inferior performance, while legitimacy theory suggests that firms with inferior SP will disclose their performance to influence the public perceptions about their sustainability performance.

Legitimacy theory predicts that firms with inferior sustainability performance will voluntarily disclose sustainability information, to legitimize their actions within the bounds of what society identifies as socially acceptable behavior (An, Davey \& Eggleton, 2011; Hummel \& Schlick, 2016; O'Donovan, 2002 and Wilmshurst \& Frost, 2000). The legitimacy of firms is threatened when stakeholders think that the long-term survival of the firm is at risk (Davis, 1973). In other words, 'organizations can only continue to exist if the society in which they are based perceives the organization to be operating a value system that is commensurate with the society's own value system' (Gray, Owen \& Adams 2009). Furthermore, the theory suggests that firms will disclose information about their SP to influence public perceptions about their performance or to inform them about their progress (Lozano and Huisingh, 2011). The purpose of signaling theory is to signal the relevant individuals within the society. Signaling theory predicts that firms with superior SP will signal their superior SP to investors and stakeholders to distinguish themselves from firms with inferior SP (Connelly, Certo, Ireland and Reutzel, 2011; Verrecchia, 1983). These firms distinguish themselves from other firms because their disclosure about their SP cannot easily be mimicked by firms with inferior SP (Clarkson, Richardson \& Vasvari, 2008). Showing superior SP has the potential to yield some additional financial advantages (Clarkson et al., 2011). Dhaliwal et al. (2011) and Plumlee, Brown, Hayes and Marshall (2015) found that firms who disclose sustainability information have lower costs of equity capital. Furthermore, their analysts' coverage increases and superior SP attracts more dedicated investors who consider long-term perspectives more and play monitoring and governance roles. Signaling superior SP also results in a higher share price (Clarkson et al., 2011). However, the underlying SP of firms has to be stem with the signal, because otherwise the signal is not effective and does not faithfully represent the CSP of the firm (Morris, 1987).

Both theories have opposing views on which firms comply with sustainability reporting guidelines. However, to comply with these guidelines is a costly process (Leitoniene and Sapkauskiene, 2015). This implies that the advantages of complying must outweigh the costs, otherwise, there is no point in complying. If firms with inferior SP comply with sustainability reporting guidelines it is difficult for firms to mask their inferior SP (Cho and Patten, 2007). However, for firms with superior SP, the intend of complying is to increase the reliability of their reports. This means that their SP is indeed superior and this is faithfully represented in their reports (Hahn and Kühnen,2013). 


\section{Methodology}

The research design adopted for this study is an ex-post facto research design. The ex-post panel survey assumes the use of cross-section heterogeneity and time heterogeneity among the companies sampled. Data were being sourced from the annual reports and accounts of quoted companies in Nigeria since data is secondary. The population of the study is the entire quoted oil and gas marketing companies in Nigeria which stood at 13 companies as of the year 2020. The census sampling technique was employed in arriving at the sample and since the study is utilizing the entire population. The justification for the sampled companies was based on the fact that oil and gas companies have a high level of economic, social and environmental impact on the communities in which they are situated. The study covered five years ranging from 2016-2020. The panel data regression technique was employed in the analysis of the data.

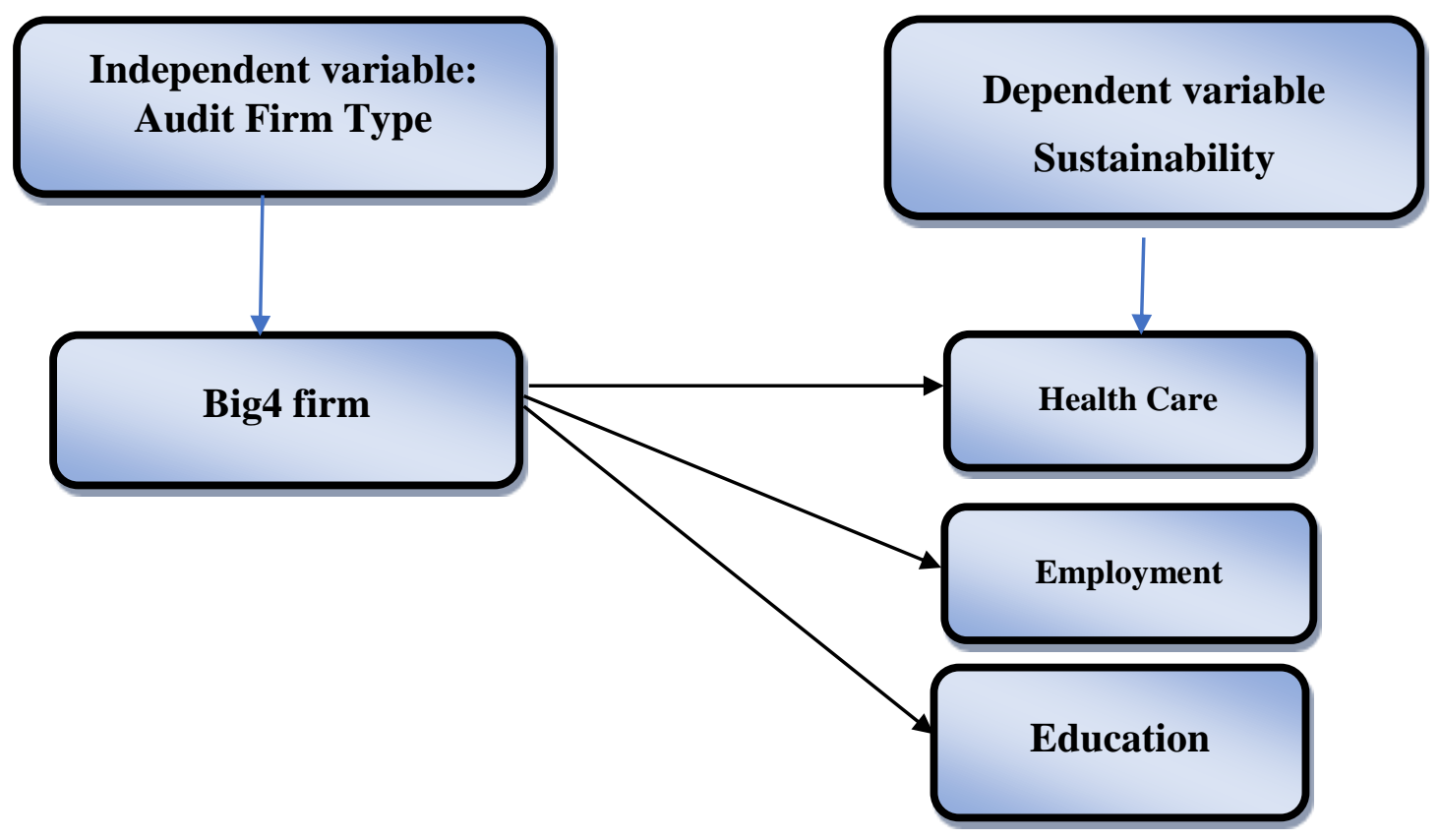

Figure 1: Nature of Relationship Between the Variables of the Study

The conceptual framework shows the relationship betweem both the independent and dependent variables with the proxies to measure them. 
Volume 1 No I November 2021

Table 1. Variables Description

\begin{tabular}{|l|l|}
\hline Variables & Measurement \\
\hline Audit Firm Type (Independent Variable) & $\begin{array}{l}\text { Represented with Dummy Variable of 1 if the } \\
\text { company is being Audited by any of the Big4 } \\
\text { audit firms. (KPMG, Deloitte, Ernst Young } \\
\text { and PWC } \\
\text { audit firm. and 0 if audited by a non-big4 }\end{array}$ \\
\hline $\begin{array}{l}\text { Sustainability Performance (Dependent } \\
\text { variable) }\end{array}$ & $\begin{array}{l}\text { The proxies for measuring dependent variable } \\
\text { (social) are expenses incurred on health care, } \\
\text { employment, and education }\end{array}$ \\
\hline
\end{tabular}

Authors' Design (2021)

\subsection{Model Specification}

The model assumed that the dependent variable is a linear function of the independent variable with consideration to the heterogeneity in the panel companies. This means that the panel regression model assumes that there is no difference in the panel companies.

\section{Model: Audit Firm Type and Sustainability performance}

$\operatorname{SUSP}_{\mathrm{it}}=\beta_{0}+\beta_{1} \mathrm{AUFT}_{\mathrm{it}}+\varepsilon_{\mathrm{it}}$

$\mathrm{HLC}_{\mathrm{it}}=\beta_{0}+\beta_{1} \mathrm{AUFT}_{\mathrm{it}}+\varepsilon_{\mathrm{it}}$.

$\mathrm{EPY}_{\mathrm{it}}=\beta_{0}+\beta_{1} \mathrm{AUFT}_{\mathrm{it}}+\varepsilon_{\mathrm{i}}$

$\mathrm{EDU}_{\mathrm{it}}=\beta_{0}+\beta_{1} \mathrm{AUFT}_{\mathrm{it}}+\varepsilon_{\mathrm{it}}$

Where:

SUSP $_{\text {it }}=$ sustainability performance

$\beta_{0} \quad=$ constant

$\beta_{1} \quad=$ variable that varies across companies

AUFT $_{\text {it }}=$ Audit Firm Type

$\varepsilon_{\mathrm{it}} \quad=$ Error term

HLT = Health care

EPY $=$ Employment

EDU $=$ Education 


\section{Finding and Discussion}

After collection and anlysis of data the results are presented as follows;

Table 2 Descriptive Statistics of Variables of Dependent and Independent Variables

\begin{tabular}{|llllllll|}
\hline Variable & Mean & $\begin{array}{l}\text { Standard } \\
\text { deviation }\end{array}$ & Minimum & Maximum & Variance & Skewness & kurtosis \\
\hline Aufty & 0.75 & 0.4385 & 0 & 1 & 0.1923 & -1.1547 & 2.3333 \\
HLT & 4.6641 & 2.8012 & 0 & 1.7740 & 7.8514 & 6.0817 & 38.0051 \\
EPY & 1.4211 & 4.9321 & 0 & 3.0621 & 2.4310 & 5.3766 & 32.1073 \\
EDU & 5.7167 & 2.4411 & 0 & 1.5522 & 5.9710 & 5.9181 & 36.6754 \\
\hline
\end{tabular}

Source: Authors' computation 2021

Table 2 revealed the descriptive statistics of the variables used in the study. Audit Firm Type (Aufty) has a mean value of 0.75 while the standard deviation is 0.4385 . This revealed a mean level of disparities and deviation. Health (HLT) has a mean value of 4.6641 and a standard deviation value of 2.8012. This revealed that the variables are not too far from each other. Employment (EPY) revealed a mean value of 1.4211 while the standard deviation value is 4.9321. Education (EDU) has a mean value of 5.7167 and the standard deviation value has a value of 2.4411 .

Variance displayed how far the number is spread out, the variance shows that Aufty, Health Care, Employment, and Education are 0.1923, 7.8514, 2.4310, and 5.9710 respectively. This implied that there is a low spread out of number.

From the results of skewness, the acceptable values of skewness fall between -3 and +3 , it shows that health care, Employment and Education are skewed to the right because the coefficients are 6.0817, 5.3766 and 5.9181 respectively likewise Audit Type are skewed to the left with the coefficient of -1.1547 which implied that the value is normal.

The appropriate range of Kurtosis is -10 to +10 (Brown, 2006). Therefore, the results of Kurtosis revealed the level of normality of data. Table 2 also revealed the kurtosis of Audit Firm type, Health care, Employment and Education are 2.333, 38.0051, 32.1073 and 36.6754 respectively which indicate that the data is not normally distributed.

\subsection{Correlation analysis of Dependent and Independent Variables}

The correlation matrix was used to determine the degree of relationship between variables of the study. These associations among the variables of the study are presented in Table 3. It gives the existence of a relationship among the variables which can be either positive or negative. A value closer to 1 depicts that the two variables are highly positively related to each other indicating multicollinearity. 
Volume 1 No I November 2021

Table 3: Correlation Matrix of Dependent and Independent Variables

\begin{tabular}{|lllrl|}
\hline & AUFTY & HLT & EPY & EDU \\
AUFTY & 1.0000 & & & \\
HLT & 0.0965 & 1.0000 & & \\
EPY & 0.1474 & -0.0467 & 1.0000 & \\
EDU & 0.1306 & 0.9918 & -0.0354 & 1.0000 \\
\hline
\end{tabular}

Source: Authors' computation 2021

Table 3 revealed the correlation matrix of the variables used in this study. Audit firm type has a positive relationship with health care, employment and education. health care has a negative relationship with employment and a positive relationship with education. employment has a negative relationship with education. it can be observed that the relationship between the independent variables themselves is not significant, an indication of the absence of multicollinearity. This can be observed from the two indicators (i.e. Tolerance value and Variance Inflation Factor (VIF) which are within less than 1 and less than 10 respectively.

Table 4 Presents the VIF results of the study which revealed the multicollinearity test of the variables.

Table 4 Multicollinearity Test

\begin{tabular}{lrl} 
Variable & VIF & $1 /$ VIF \\
\hline HLT & 61.90 & 0.01615 \\
EPY & 61.85 & 0.01617 \\
EDU & 1.01 & 0.99058 \\
\hline
\end{tabular}

Mean VIF 41.59

Source: Authors' computation 2021

Table 4 shows the multicollinearity test which shows the VIF value is above 10 which indicated the presence of a multicollinearity problem. The VIF of the HLT shows 61.90, EPY is 61.85, and EDU is 1.01 which showed that all independent variables have no serious multicollinearity and likewise the tolerance value (DF) showed $0.01615,0.1617$, and 0.99058 for HLT, EPY and EDU respectively.

\subsection{Regression Analysis}

This section presents the regression results of dependent and independent variables of the study which provided a test of the hypotheses.

Hypothesis One: Audit Firm Type has no significant effect on health care of Oil and Gas Marketing Companies in Nigeria. 


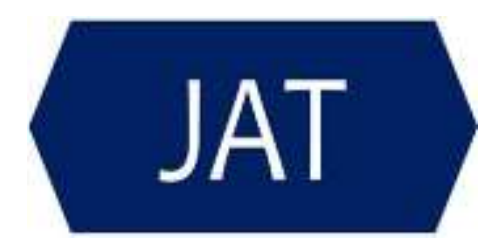

Volume 1 No 1 November 2021

Table 5: Audit Firm Type and Health Care

\begin{tabular}{lll}
\hline & Coefficient & P-value \\
\hline Constant $(\boldsymbol{C})$ & 0.7429 & 0.000 \\
Health & 1.5100 & 0.554 \\
\hline R-Square & 0.0093 & \\
Adj. R- Square & 0.0168 & \\
Wild Chi 2 & 0.4422 & \\
P>chi 2 & 0.5535 & \\
\hline
\end{tabular}

Source: Authors' computation 2021

Table 5 shows that there is a positive and no significant relationship between AUFTY and HLT, on listed Oil and Gas Marketing companies in Nigeria with a p-value of 0.554 and coefficient are 1.5100, which indicate that we reject null hypotheses and accept alternative hypothesis which says AUFTY has a significant effect on HLT on listed Oil and Gas marketing companies in Nigeria.

Hypothesis Two: Audit Firm Type has no significant effect on Employment of Oil and Gas Marketing Companies in Nigeria.

Table 6: Audit Firm Type and Employment

\begin{tabular}{lll}
\hline & Coefficient & P-value \\
\hline Constant $(\boldsymbol{C})$ & 0.7314 & 0.000 \\
Employment & 1.3128 & 0.364 \\
\hline R-Square & 0.0217 & \\
Adj. R- Square & 0.0040 & \\
Wild Chi 2 & 0.4394 & \\
P>chi 2 & 0.3639 & \\
\hline
\end{tabular}

Source: Authors' computation 2021

Table 6 shows that there is a positive and no significant relationship between AUFTY and EPY, on listed Oil and Gas Marketing companies in Nigeria with a p-value of 0.364 and coefficient are 1.3128, which indicate that we reject null hypotheses and accept alternative hypothesis which says AUFTY has a significant effect on EPY on listed Oil and Gas marketing companies in Nigeria.

Hypothesis Three: Audit Firm Type has no significant effect on Education of Oil and Gas Marketing Companies in Nigeria.

Table 7 shows that there is a positive and no significant relationship between AUFTY and EDU, on listed Oil and Gas Marketing companies in Nigeria with a p-value of 0.422 and a coefficient is 2.3410 which indicate that we reject null hypotheses and accept an alternative hypothesis that says AUFTY has a significant effect on EDU on listed Oil and Gas marketing companies in Nigeria. 
Table 7: Audit Firm Type and Education

\begin{tabular}{lll}
\hline & Coefficient & P-value \\
\hline Constant $(\boldsymbol{C})$ & 0.7366 & 0.000 \\
Education & 2.3410 & 0.422 \\
\hline R-Square & 0.0170 & \\
Adj. R- Square & 0.0088 & \\
Wild Chi 2 & 0.4405 & \\
P>chi 2 & 0.4219 & \\
\hline
\end{tabular}

Source: Authors' computation 2021

\section{Conclusion}

From the findings of the study, it can be deduced that corporate governance mechanisms play a very crucial role in the performance of a firm in terms of their sustainability efforts and specifically the role played by the audit firm type. From the study, therefore, the findings revealed that there is no significant relationship between Audit Firm Type and Health care, Employment and Education of listed Oil and Gas Marketing companies in Nigeria, even though the relationships are positive. This signifies that the performance of firms in the area of Sustainability is not a result of the type of audit firm that audited these oil companies but can be attributed to other factors. In line with the findings of the study, the study recommends that Managements of listed Oil and Gas marketing companies in Nigeria should continually keep to their effort of performing better in terms of their sustainability without recourse to whether they are being audited by the Big 4 audit firm or the non-Big 4 audit firms but rather strive to continually comply with regulatory framework and policies to keep their firms at a competitive advantage over others.

\section{References}

Amacha, E. B., \& Dastane, O. (2017). Sustainability practices as determinants of financial performance: A case of Malaysian corporations. Journal of Asian Finance, Economics and Business, 4(2), 55-68. https://doi.org/10.13106/jafeb.2017. vol4.no2.55

Aras, G., \& Crowther, D. (2008). Governance and sustainability. Management Decision, 46(3), 433-448. https://doi.org/ 10.1108/00251740810863870

Ashok K. S. (2018), Impact Of Corporate Governance On Sustainability: A Study Of The Indian FMCG Industry

Bebbington, J., Unerman, J., \& O'DWYER, B. R. E. N. D. A. N. (2014). Introduction to sustainability accounting and accountability. In Sustainability accounting and accountability (pp. 21-32). Routledge.

Brammer, S., \& Pavelin, S. (2006). Voluntary environmental disclosures by large UK companies. Journal of Business Finance \& Accounting, 33(7-8), 1168-1188.

Berrone, P.; Cruz, C.; Gomez-Mejia, L.R.; Larraza-Kintana, M. (2006). Socioemotional Wealth and Corporate Responses to Institutional Pressures: Do Family-Controlled Firms Pollute Less? Adm. Sci. Q. 2010, 55, 82-113. 
Belal, A.R. (2016). Corporate Social Responsibility Reporting in Developing Countries: The Case of Bangladesh; Routledge: Oxford, UK.

Connelly, B. L., Certo, S. T., Ireland, R. D., \& Reutzel, C. R. (2011). Signaling theory: A review and assessment. Journal of Management, 37(1), 39-67. https://doi. org/10.1177/0149206310388419

Deegan, C. (2014). An analysis of the incentives of Australian firms to provide environmental information within their annual report. Accounting Group Seminar in Church land campus, New South Wales

Escrig-Olmedo, E., Muñoz-Torres, M. J., Fernández-Izquierdo, M. Á., \& Rivera-Lirio, J. M. (2017). Measuring corporate environmental performance: A methodology for sustainable development. Business Strategy and the Environment, 26(2), 142-162. https://doi.org/10.1002/bse.1904

Franco R. \& Francesco N (2020) What Impact Does Corporate Governance Have on Corporate Environmental Performances? An Empirical Study of Italian Listed Firm.

Gray, R., Owen, R., \& Adam, S. (2009). Corporate social and environmental reporting. Accounting, Auditing \& Accountability Journal, 8(2), 47-77. https://doi. org/10.1108/09513579510146996

Galbreath, J. (2018). The impact of strategic orientation on corporate social responsibility. International Journal of Organizational Analysis, 18(1), 23-40.

Hussain, N., Rigoni, U., \& Orij, R. P. (2018). Corporate governance and sustainability performance: Analysis of triple bottom line performance. Journal of Business Ethics, 149(2), 411-432. https://doi.org/10.1007/s10551-016-3099-5

Hummel, K.; Schlick, C. (2016). The Relationship between Sustainability Performance and Sustainability Disclosure-Reconciling Voluntary Disclosure Theory and Legitimacy Theory. J. Account. Public Policy 2016, 35, 455-476

Jensen, M. C., \& Meckling, W. H. (1979). Theory of the firm: Managerial behavior, agency costs, and ownership structure Economics social institutions (pp. 163-231): Springer

Martins, V. W. B., Rampasso, I. S., Anholon, R., Quelhas, O. L. G., \& Leal Filho, W. (2019). Knowledge management in the context of sustainability: Literature review and opportunities for future research. Journal of Cleaner Production, 229, 489- 500. https://doi.org/10.1016/j.jclepro.2019.04.354

Milne, M.J. \& Gray, R. (2013). W(h)ither ecology? The triple bottom line, the global reporting initiative and corporate sustainability reporting. Journal of Business Ethics, 118(1), 13-29

Milne, M. J., Tregidga, H., \& Walton, S. (2009). Words not actions! The ideological role of sustainable development reporting.Accounting, Auditing \& Accountability Journal, 22(8), 1211-1257. https://doi.org/10.1108/09513570910999292

Shleifer, A.\& Vishny, R. A (1997). Survey of Corporate Governance. J. Finance. 1996, 52, 737-783.

Setyahadi \& Narsa (2020) Corporate Governance and Sustainability in Indonesia. Journal of Asian Finance, Economics and Business Vol 7 No 12 (2020) 885-894

Usman, B. (2020). CSR performance, firm's attributes, and sustainability reporting. International Journal of Business and Society, 21(2), 521-539. 
Zeeshan M. D, Rehana K., Waris A., Zubair A. \& Tahira S. (2020); Does Corporate Governance Affect Sustainability Disclosure? A Mixed Methods Study. Department of Commerce, Bahauddin Zakariya University, Multan 60800, Pakistan; zeeshanmahmood@bzu.edu.pk (Z.M.); tahirasalman6@gmail.com (T.S.)

\section{Copyrights}

Copyright for this article is retained by the author(s), with first publication rights granted to the journal.

This is an open-access article distributed under the terms and conditions of the Creative Commons Attribution license (http://creativecommons.org/licenses/by/4.0/) 